\title{
Relationship between student learning interest and mathematics learning achievement: A meta-analysis
}

\section{La Ili ${ }^{1}$, Muhammad Irfan Rumasoreng ${ }^{*}$, Anggit Prabowo ${ }^{3}$, Dafid Slamet Setiana ${ }^{4}$,Adam Latuconsina ${ }^{5}$}

${ }^{1}$ Universitas Halu Oleo, Indonesia.

${ }^{2}$ Universitas Mercu Buana Yogyakarta, Indonesia.

${ }^{3}$ Universitas Ahmad Dahlan, Indonesia.

${ }^{4}$ Universitas Sarjanawiyata Tamansiswa Yogyakarta, Indonesia.

${ }^{5}$ Institut Agama Islam Negeri Ambon

$\triangle$ muhirfan@mercubuana-yogya.ac.id

\section{Article Information}

Submitted Aug 17, 2021

Revised Dec 06, 2021

Accepted Dec 11, 2021

\section{Keywords}

Meta-Analysis; Learning Interest; Learning Achievement; Mathematics; Student.

\begin{abstract}
Mathematics is regarded as one of the most important lessons that any student must learn. Internal and external factors, in general, influence students' mathematics learning achievement. One of the internal factor variables is students' learning interest in mathematics. Many research publications show that the variable of interest is strongly related to mathematics learning achievement, so this study aims to prove and quantify the size of the relationship between mathematics learning interest and mathematics learning achievement using quantitative metaanalysis research approaches. The independent variable is student learning interest, and the dependent variable is mathematical learning achievement. The data was acquired from an online database search on Google Scholar within the 2009 to 2019 timeframe. Thirty research publications that satisfied the required criteria were utilized as the sample. Data analysis uses a quantitative meta-analysis approach with a correlation meta-analysis. The findings revealed a favorable and substantial (5\% significance level) link between learning interest and student mathematics learning achievement. The average weight value of effect size was 0.540 in the range of 0.430 to 0.640 in the medium category. These findings have demonstrated the consistency of previous researchers' conclusions.
\end{abstract}

\section{INTRODUCTION}

Mathematics is one of the subjects that is considered difficult. When learning mathematics, few students experience fear (Pieronkiewicz, 2017), stress, and anxiety (Sokolowski \& Ansari, 2017). Mathematics contains facts and procedures, quantity, forms, and relationships. It is considered a science, an art, a skill, and a means to understand the surrounding environment and mind (Schoenfeld, 2016). Considering its complexity, effective efforts and strategies are needed to teach mathematics to help students understand and improve their mathematics learning achievement.

Mathematics learning achievement can be seen from the teacher's mastery of mathematics subject matter. Student learning achievement is measured using a test instrument. Based on the calculation of test results, students' high or low achievement levels are influenced by two factors: external and internal factors. External factors exist outside of students, for example, neighborhood, family background, school conditions (infrastructure, location, school size, atmosphere, and number and composition of students), and teachers 
(professional training, teaching attitudes, teaching motivation, and collaboration) (Széll, 2013). On the other hand, internal factors exist within students, for example, motivation (Kirkham et al., 2020), talent (Mazana et al., 2019), and interest (Weber et al., 2005).

Interest is thought to predict achieving mathematical learning outcomes while also making students not fear mathematics (Heinze et al., 2005). Individual interests tend to last longer (Renninger, 2000). There are four dimensions of learning interest mathematics, namely interest in a particular domain, interest in a particular subject or topic in a domain, interest in a particular context embedded in a topic, and interest in certain activities that are connected to a context/topic (Blankenburg et al., 2016). Conceptual interest constructs are related to values and enjoyment (Frenzel et al., 2010). Interest is directly influenced by motivation and confidence, with an indirect effect of anxiety and usefulness (Otoo et al., 2018).

Students who have a high interest in a subject will have a good learning outcome (Weber et al., 2005). Students who have a learning interest will have greater academic effort (Trautwein et al., 2015), can organize their learning well (Lee et al., 2014), focus their attention, get involved in an activity, intensity, concentration, and perseverance in learning (Winne \& Nesbit, 2010). In Indonesia, there has been a lot of research on the relationship between students' learning interests and mathematics learning achievements. Some of the results of the study show that there is a relationship between students' learning interest and mathematics learning achievement (Wahid, 2009; Anggreini, 2010; Adhitama, 2011; Safitri, 2012; Putri \& Widodo, 2018; Wardiana et al., 2014; Siagian, 2015; Sirait, 2016; Heriyati, 2017; Ari, 2020; Fitriyani, 2019). The correlation coefficients $\left(\mathrm{r}_{\mathrm{xy}}\right)$ obtained are very diverse, as shown in table 1 . However, the findings must be proven by meta-analysis.

Meta-analysis is a statistical analysis that combines several similar studies (Enwemeka et al., 2004). Meta-analysis is also used to obtain previous systematic studies to obtain conclusions from the research framework (Haidich, 2010). Meta-analysis is a container that can load other studios and then analyze using a new analysis plan and standards (Kilpeläinen et al., 2011; Koricheva et al., 2013). A meta-analysis combines results from several studios and compares several treatments or interventions (White, 2015; Riley et al., 2010). Metaanalyzes can summarize and explain certain phenomena more broadly (Stanley et al., 2013; Green, 2005). The meta-analysis can contain a complete literature analysis using appropriate statistical techniques (Junhua et al., 2007).

The benefit of meta-analysis is that it can combine various research into a quantitative manner, link between studies, be more objective, focus on effect size, and be easy to do (King \& He, 2006). Another advantage of meta-analysis allows aggregate data to be reported in detail, avoids the threat of publication bias, and reports more selective research (Riley et al., 2010). Also, research using statistical meta-analysis techniques can summarize the evidence for decision-makers who do not need much time to look for a variety of primary evidence (Green, 2005). It can limit bias, appraise critically, and provide research conclusions from various specific studies (Akobeng, 2005).

Many studies link interest and learning achievement (Astuti, 2015; Charli et al., 2019; Ratnasari, 2017; Sirait, 2016), but there has been no research that shows the impact on learning mathematics. It is necessary to deepen the existing research. The researchers were interested in conducting quantitative meta-analysis research based on the description. The first objective of this research is to investigate the effect size of the relationship between students' 
learning interests and students' mathematics learning achievement in Indonesia. The second objective is testing or proving the relationship between students' learning interests and students' mathematical learning in Indonesia.

\section{METHODS}

The research design used was a quantitative meta-analysis (Hunter \& Schmidt, 2004). A quantitative meta-analysis combines two or more published research results for statistical analysis. The research publications are related to the influence or relationship between students' learning interests towards mathematics learning outcomes. The meta-analysis stages (DeCoster, 2004) are determining interesting relationships, gathering populations that provide the data, determining the study specifically and assessing the effect size, examining the effect size, analyzing the impact of moderating variables, and interpreting and reporting the results. In the meta-analysis, there are fixed effects and random effects statistical models. The fixedeffect meta-analysis assumes all studies have the same treatment effect, while random effects assume all studies have different treatments (Riley et al., 2010).

\section{Feasibility Criteria}

Several standard feasibility criteria are used to screen or select research publications in the Google Scholar online database. The first standard is the formats, consisting of the journal, proceeding, bachelor's thesis, master's thesis, and doctoral dissertation. The next standards are that the research must be conducted in Indonesia, can be accessed in the Google Scholar online database, contain the mathematics learning interest and mathematics learning achievement variables, are published at least in the last 10 years, and have a correlation value $\left(\mathrm{r}_{\mathrm{xy}}\right)$ which explains the relationship between mathematics learning interest and mathematics learning achievement variables.

\section{Data Collection}

The data had been collected by accessing the Google Scholar database. The publications must be related to the relationship or influence of mathematics learning interest and achievement variables. In facilitating the search in Google Scholar's online database, the researchers employed the following keywords: 'mathematics interest,' 'mathematics learning interest,' 'mathematics learning achievement,' and 'mathematics achievement.

\section{Coding and Data analysis}

The researchers performed coding to process and analyze the data. The codes consisted of publication year $(\mathrm{T})$, sample size $(\mathrm{N})$, correlation $\left(\mathrm{r}_{\mathrm{xy}}\right)$, mathematics learning interest variables (Independent), and mathematics learning achievement variables (Dependent). The analysis of the data refers to the opinions of (Grasman, 2017, Borenstein et al., 2009; Hunter \& Schmidt, 2004), as follows: (a) sample characteristics; (b) heterogeneity test; (c) checking publication bias; (d) estimating the effect size and effect size summary; (e) making forest plots; and (f) calculating p-values to test hypotheses. The researchers utilized Jeffrey's Amazing Statistics Program (JASP. 0.8. 4.0.) in analyzing the data.

\section{RESULTS AND DISCUSSION}


There are several stages of analysis to achieve research objectives. This analysis began by describing the characteristics of the research sample. The data is displayed in Table 1.

Table 1. The Characteristics of Sample

\begin{tabular}{|c|c|c|c|c|c|}
\hline Year & Author & Publication & $\mathbf{N}$ & $\mathbf{R}_{\mathbf{x y}}$ & Characteristics \\
\hline 2016 & Sirait & Journal & 65 & 0.706 & SMP students \\
\hline 2015 & Siagian & Journal & 30 & 0.109 & SMK students \\
\hline 2018 & Rahmawati, Krisdiana,\&Suprato & Proceeding & 185 & 0.503 & SMP students \\
\hline 2009 & Wahid & Undergraduate thesis & 54 & 0.493 & SMA students \\
\hline 2015 & Daniyati \& Sugiman & Journal & 360 & 0.248 & SMP students \\
\hline 2014 & Wardiana, Wiarta, \& Zulaikha & Journal & 182 & 0.575 & SD students \\
\hline 2016 & Purnama & Journal & 98 & 0.655 & SMA students \\
\hline 2018 & Fatonah, Purnami, \& Agustito & Proceeding & 89 & 0.286 & SMP students \\
\hline 2016 & Handayani & Journal & 100 & 0.204 & SMK students \\
\hline 2019 & Islamiah & Journal & 36 & 0.224 & SMK students \\
\hline 2015 & Nurrahmah & Journal & 150 & 0.420 & SMP students \\
\hline 2018 & Wanasari & Undergraduate thesis & 98 & 0.843 & SMP students \\
\hline 2018 & Putri & Undergraduate thesis & 61 & 0.270 & SD students \\
\hline 2017 & Heriyati & Jurnal & 63 & 0.568 & SMP students \\
\hline 2019 & Angrayana, Darsono \& Sugiman & Journal & 28 & 0.511 & SD students \\
\hline 2017 & Allantara, Darsono, \& Wahab & Journal & 35 & 0.416 & SD students \\
\hline 2019 & Fitriyani & Journal & 224 & 0.640 & SMP students \\
\hline 2018 & Hamdani & Journal & 100 & 0.236 & SMP students \\
\hline 2010 & Anggreini & Undergraduate thesis & 79 & 0.279 & SMP students \\
\hline 2010 & Agustiningsih & Undergraduate thesis & 80 & 0.226 & SMP students \\
\hline 2017 & Music & Undergraduate thesis & 112 & 0.473 & SMP students \\
\hline 2017 & Muti'ah & Journal & 41 & 0.612 & SMP students \\
\hline 2011 & Adhitama & Undergraduate thesis & 40 & 0.820 & SMP students \\
\hline 2012 & Safitri & Undergraduate thesis & 42 & 0.468 & SD students \\
\hline 2013 & Fathallah & Undergraduate thesis & 30 & 0.848 & SMP students \\
\hline 2013 & Setiawan & Undergraduate thesis & 74 & 0.673 & SD students \\
\hline 2019 & Setiyani & Undergraduate thesis & 67 & 0.432 & SD students \\
\hline 2016 & Lestari \& Arigiyati & Journal & 123 & 0.242 & SMP students \\
\hline 2016 & Hartanti \& Harini & Journal & 48 & 0.343 & SMK students \\
\hline 2016 & Retno & Undergraduate thesis & 32 & 0.548 & MI Student \\
\hline
\end{tabular}

Information: SD = Elementary School; MI = Islamic Elementary School; SMP = Junior High School; SMA = Senior High School; and SMK = Vocational High School.

Based on the table above, the research publications have varying $\mathrm{N}$ and $\mathrm{r}$ values. The size of the $\mathrm{N}$ value is at an interval of 28 to 360, while the value of $\mathrm{r}$ is at an interval of 0.109 to 0.848 . Each publication has a positive r-value, which indicates a positive relationship between students' learning interests and students' mathematics learning achievement. The description of the samples' frequency by year and the form of publication are presented in table 2

Table 2. Year of publication and the Forms of Publication

\begin{tabular}{cccc}
\hline & & Frequency $(\mathrm{F})$ & Percentage (\%) \\
\hline \multirow{3}{*}{$\begin{array}{c}\text { Year of } \\
\text { publication }\end{array}$} & 2009 & 1 & 3.3 \\
\cline { 2 - 4 } & 2010 & 2 & 6.7 \\
\cline { 2 - 4 } & 2011 & 1 & 3.3 \\
\cline { 2 - 4 } & 2012 & 1 & 3.3 \\
\hline
\end{tabular}




\begin{tabular}{cccc}
\hline \multirow{4}{*}{2013} & 2 & 6.7 \\
\cline { 2 - 4 } & 2014 & 1 & 3.3 \\
\cline { 2 - 4 } & 2015 & 3 & 10.0 \\
\cline { 2 - 4 } & 2016 & 6 & 20.0 \\
\cline { 2 - 4 } & 2017 & 5 & 16.7 \\
\cline { 2 - 4 } & 2018 & 4 & 13.3 \\
\hline \multirow{2}{*}{$\begin{array}{c}\text { Form of } \\
\text { publication }\end{array}$} & Undergraduate thesis & 4 & 13.3 \\
\cline { 2 - 4 } & Proceeding & 2 & 60.0 \\
\cline { 2 - 4 } & Journal & 16 & 53.3 \\
\hline
\end{tabular}

The research samples were taken based on the 2009 to 2019 intervals. The highest number of publications was found in 2016, with six publications $(20.0 \%)$. The formats of publication were dominated by undergraduate theses with 12 publications (40.0\%), proceeding with two publications (6.7\%), and journals with 16 publications (53.3\%). Therefore, journal publication was the most common format of publication. The next step was testing the research samples' literacy. Based on the analysis results, the $\mathrm{Q}$ values are presented in table 3 .

Tabel 3. Fixed and Random Effect

\begin{tabular}{lccc}
\hline & Q & df & p \\
\hline Omnibus test of Model Coefficients & 97.290 & 1 & $<0.001$ \\
Test of Residual Heterogeneity & 195.890 & 29 & $<0.001$ \\
\hline
\end{tabular}

Based on Table 3, the obtained Q value was 195.890. Furthermore, the obtained p-value was 0.001 , which was lower than 0.05 . The results indicated that the research sample (publication) was based on $\mathrm{r}$ (literacy) value. Also, these results were confirmed or supported by the results of estimating heterogeneity residuals. Estimation results showed that the value of $\tau^{2}$ was 0.073 , which was higher than 0 . The total value of $\tau$ was 0.279 and higher than 0 . The value of $I^{2}$ was $86.2 \%$, approaching $100 \%$. Thus, the publication bias, weight effect size, summary effect size, and p-value were analyzed using a random effect approach. The next stage was the publication bias analysis. Based on the analysis results using the random effect approach, the values of Kendal and $\mathrm{Z}$ are presented in table 4.

Table 4. Rank Correlation Test for Funnel Plot Asymmetry dan Regression Test for Funnel Plot Asymmetry (Egger's Test)

\begin{tabular}{ccc}
\hline & Kendall's $\tau$ & $\mathrm{P}$ \\
\hline Rank test & 0.134 & 0.301 \\
\hline Sei & $\mathrm{Z}$ & $\mathrm{P}$ \\
\hline & 0.703 & 0.482 \\
\hline
\end{tabular}

Based on the table above, the Kendal value $\tau$ was 0.134 with a p-value of 0.301 (lower than 0.05 ). The $Z$ value was 0.703 with a $p$-value of 0.482 (lower than 0.05 ). The researchers concluded that there was no publication bias. These results were confirmed or supported by a funnel diagnostic with the trim-fill analysis presented in Figures 1 and 2. 


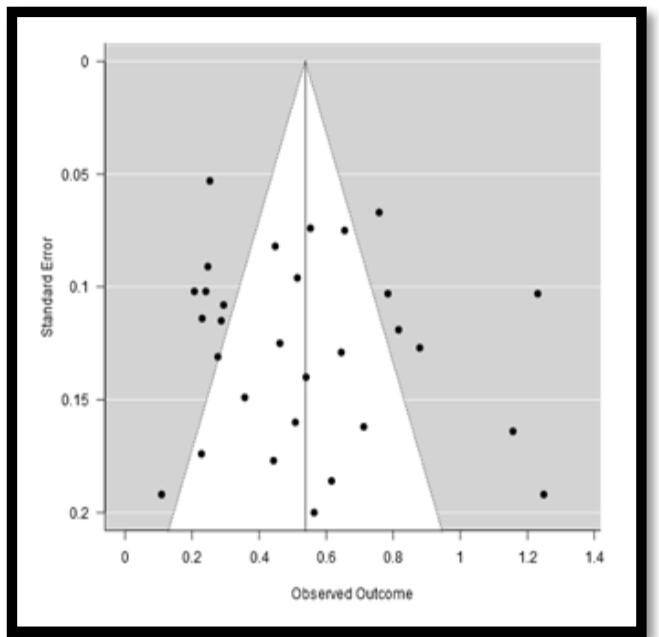

Figure 1. Initial Funnel Plot

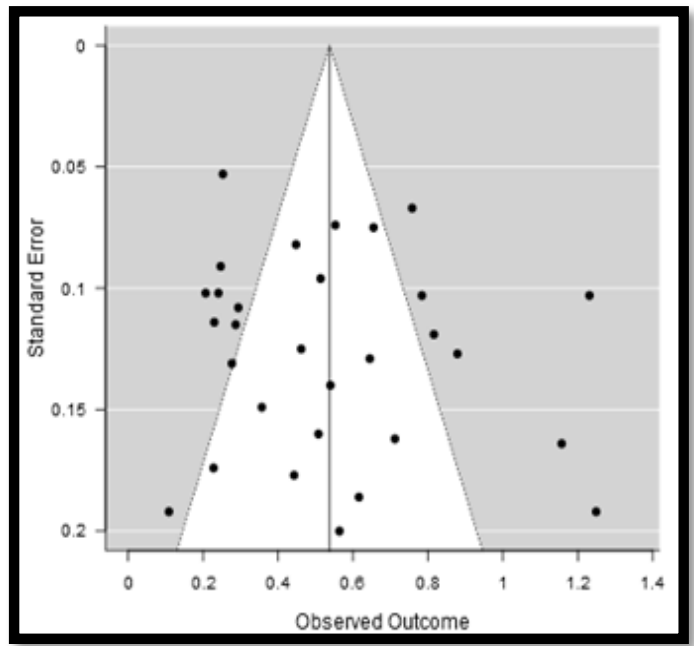

Figure 2. Funnel Diagnostic Plots with Trim-Fill Analysis

Figure 1 shows the initial funnel plot or diagnostic, while Figure 2 shows the funnel plot diagnostic with a trim-fill analysis approach. The two figures do not display any difference. Figure 2 shows the distribution of full and symmetry black dots. There are no blank spots that characterize publication bias. Therefore, there was no publication bias, and there was no need to add samples into the data analysis. The next stage was calculating the summary effect size. The results of calculations involving the weight ofthe effect size of each publication are presented in Figure 3.

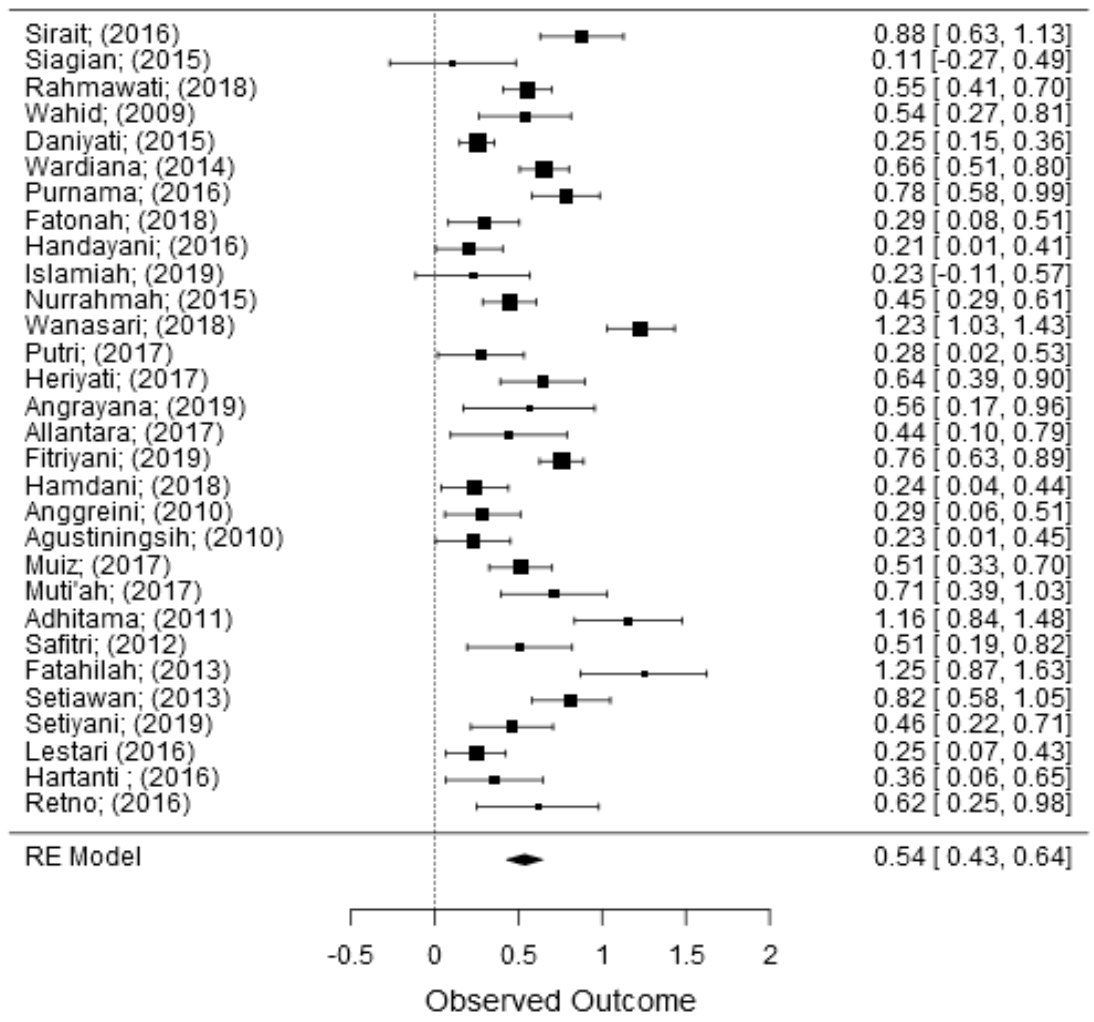


Figure 3. Forest Plot Based on Random Fixed

Based on Figure 3, each weight effect size is at its interval. For example, publication 1 with a weight of 0.880 is at an interval of 0.630 to 1.130 ; publication 2 with a weight of 0.110 is at an interval of -0.270 to 0.490 ; publication 3 with a weight of 0.550 is at an interval of 0.410 to 0.700 ; etc. The weight of the effect size was diverse. The average weight of effect size was 0.540 at an interval of 0.430 to 0.640 . The resulting variance was 0.0028 , and the standard error was 0.053 .

The next stage was calculating the p-value to test the following hypothesis:

Ho: There is no significant relationship between students' learning interest and their mathematics learning achievement

Ha: There is a significant relationship between students' learning interests with their mathematics learning achievement

The calculation involving the weighted average effect size and standard error obtained a $\mathrm{Z}$ value of 10.189 . The $\mathrm{Z}$ value obtained was substituted into the $\mathrm{p}$-value equation $=1$ NORMSDIST $(Z)$ in the one-tailed test approach with a significant level of $95 \%$. The obtained p-value was lower than 0.05 . Therefore, $\mathrm{H}_{\mathrm{o}}$ was rejected. It means a significant relationship between students' learning interest and their mathematics learning achievement.

Students' mathematics learning achievement measures their success in absorbing mathematical material within a certain time frame. A test instrument is a tool that can be used to measure and assess students' mathematical absorption while studying at school. Based on the test results, students' mathematical achievement is low or high. Apart from that, many factors influence students' mathematics learning achievement. Learning interest is one factor that influences mathematics learning achievement (Fitriyani, 2019). In Indonesia, there has been a lot of research about the relationship between learning interest and mathematics learning achievement.

Based on the results of data analysis from 30 research publications in Indonesia about the relationship between learning interest and mathematics learning achievement through the meta-analysis approach, the weighting effect ratio of 0.540 was obtained. According to (Cohen et al., 2007), this value is in the medium category. The weight obtained is inseparable from the small value of the resulting variance $(0.0028)$ and the standard error (0.053). Also, there is no publication bias which shows that the research sample used was valid. The absence of publication bias means that no publication (study) was lost in the analysis, so there is no need to add.

The weight of the positive side effect ratio shows that interest is one of the variables that positively correlates with students' success in learning mathematics, either at school, at home, or other formal institutions. Low student interest will make students not excited about learning mathematics. High interest should encourage students to be enthusiastic in learning mathematics, even though the material has a high difficulty level. Students with high learning interest will have greater academic effort (Trautwein et al., 2015), can organize their learning well (Lee et al., 2014), focus their attention, get involved in an activity (Winne \& Nesbit, 2010).

The weight size effect produced was in line with testing the research hypothesis. Based on the hypothesis testing ( $\mathrm{p}$-value <0.05), there was a significant relationship between students' learning interests and mathematics learning achievement. On this basis, teachers 
who want to teach mathematics must first foster students' love for mathematics. The teacher can recognize the most effective factors that can increase students' interest in mathematics. The teacher can provide awards to each student in the learning process, choose mathematical models, methods, approaches, or strategies that effectively encourage students to learn mathematics, create a comfortable classroom environment, and allow each student to ask.

\section{CONCLUSIONS}

It is essential to investigate learning interests' importance in improving learning achievement. Therefore, the impact of existing studies on the matter will certainly provide additional research on mathematics education. Through the meta-analysis approach, it was found that there was a positive and significant influence between students' learning interests and mathematics learning achievement in Indonesia. The average size effect obtained was 0.540 at 0.430 to 0.640 . The resulting variance was 0.0028 , the standard error was 0.053 , and there was no bias publication. These results have supported existing theories and have shown prior research consistency. Also, the results of this research have provided practical benefits for teachers, schools, and parents in teaching mathematics to every student by paying attention to interests as a motivating factor. Students with high learning interests will encourage other students to always learn mathematics even though it is difficult.

Interest is one of the factors and has been proven to have a good impact on mathematics learning achievement. Therefore, more extensive research on other subjects needs to be done to generalize the results.

\section{AUTHOR CONTRIBUTIONS STATEMENT}

In this research activity, LI is the coordinator plans research activities. MIR and AP are responsible for instrument design and data processing. DSS that makes improvements in the revision process.

\section{REFERENCES}

Adhitama, L. (2011). Hubungan antara kepribadian dan minat belajar anak terhadap prestasi matematika siswa kelas VIII di SMP negeri 1 Boyolangu tahun pelajaran 2010/2011. UIN Satu Tulung Agung.

Akobeng, A. K. (2005). Understanding systematic reviews and meta-analysis. Archives of Disease in Childhood, 90(8), 845-848.

Anggreini, L. R. (2010). Pengaruh pemberian motivasi belajar dari orang tua, minat belajar matematika, dan problema remaja terhadap prestasi belajar matematika siswa kelas VIII SMP negeri 5 Boyolali tahun pelajaran 2009/2010. Universitas Sebelas Maret.

Ari, S. (2020). Pengaruh kemandirian belajar terhadap kemampuan komunikasi matematis siswa kelas VIII di MTs negeri 5 Kebumen. IAIN Purwokerto.

Astuti, S. P. 2015. Pengaruh kemampuan awal dan minat belajar terhadap prestasi belajar fisika. Jurnal Formatif, 5(1), 68-75.

Blankenburg, J. S., Höffler, T. N., \& Parchmann, I. (2016). Fostering today what is needed tomorrow: Investigating students' interest in science. Science Education, 100(2), 364391.

Borenstein, M., Cooper, H., Hedges, L., \& Valentine, J. (2009). Effect sizes for continuous data. The Handbook of Research Synthesis and Meta-Analysis, 2, 221-235. 
Charli, L., Ariani, T., \& Asmara, L. (2019). Hubungan minat belajar terhadap prestasi belajar fisika. Science and Physics Education Journal (SPEJ), 2(2), 52-60.

Cohen, L., Manion, L., \& Morrison, K. (2007). Observation. Research Methods in Education, 6, 396-412.

DeCoster, J. (2004). Meta-analysis notes. Institute for Social Science Research University of Alabama

Enwemeka, C. S., Parker, J. C., Dowdy, D. S., Harkness, E. E., Harkness, L. E., \& Woodruff, L. D. (2004). The efficacy of low-power lasers in tissue repair and pain control: a metaanalysis study. Photomedicine and Laser Therapy, 22(4), 323-329.

Fitriyani, R. (2019). Hubungan minat belajar dan intensitas belajar dengan prestasi belajar matematika siswa kelas VII SMP negeri 1 Karanganom. Absis: Mathematics Education Journal, 1(1), 19-23.

Frenzel, A. C., Goetz, T., Pekrun, R., \& Watt, H. M. G. (2010). Development of mathematics interest in adolescence: Influences of gender, family, and school context. Journal of Research on Adolescence, 20(2), 507-537.

Grasman, R. (2017). Meta-analysis in JASP. JSAP.

Green, S. (2005). Systematic reviews and meta-analysis. Singapore Medical Journal, 46(6), 270.

Haidich, A.-B. (2010). Meta-analysis in medical research. Hippokratia, 14(Suppl 1), 29.

Heinze, A., Reiss, K., \& Franziska, R. (2005). Mathematics achievement and interest in mathematics from a differential perspective. ZDM, 37(3), 212-220.

Heriyati, H. (2017). Pengaruh minat dan motivasi belajar terhadap prestasi belajar matematika. Formatif: Jurnal Ilmiah Pendidikan MIPA, 7(1).

Hunter, J. E., \& Schmidt, F. L. (2004). Methods of meta-analysis: Correcting error and bias in research findings. Sage.

Junhua, Z., Hongcai, S., Xiumei, G., Boli, Z., Yaozu, X., Hongbo, C., \& Ming, R. (2007). Methodology and reporting quality of systematic review/meta-analysis of traditional Chinese medicine. The Journal of Alternative and Complementary Medicine, 13(8), 797-806.

Kilpeläinen, T. O., Qi, L., Brage, S., Sharp, S. J., Sonestedt, E., Demerath, E., Ahmad, T., Mora, S., Kaakinen, M., \& Sandholt, C. H. (2011). Physical activity attenuates the influence of FTO variants on obesity risk: a meta-analysis of 218,166 adults and 19,268 children. PLoS Medicine, 8(11), e1001116.

King, W. R., \& He, J. (2006). A meta-analysis of the technology acceptance model. Information and Management, 43(6), 740-755.

Kirkham, J., Chapman, E., \& Wildy, H. (2020). Factors considered by Western Australian Year 10 students in choosing Year 11 mathematics courses. Mathematics Education Research Journal, 32(4), 719-741.

Koricheva, J., Gurevitch, J., \& Mengersen, K. (2013). Handbook of meta-analysis in ecology and evolution. Princeton University Press.

Lee, W., Lee, M.-J., \& Bong, M. (2014). Testing interest and self-efficacy as predictors of academic self-regulation and achievement. Contemporary Educational Psychology, 39(2), 86-99.

Mazana, Y. M., Suero Montero, C., \& Olifage, C. R. (2019). Investigating students' attitude towards learning mathematics. International Electronic Journal Of Mathematics Education, 14(1), 207-231.

Otoo, D., Iddrisu, W. A., Kessie, J. A., \& Larbi, E. (2018). Structural model of students' interest and self-motivation to learning mathematics. Education Research International, 2018.

Pieronkiewicz, B. (2017). What are students afraid of when they say they are afraid of 
mathematics?. Springer.

Putri, I. D. C. K., \& Widodo, S. A. (2018). Hubungan antara minat belajar matematika, keaktifan belajar siswa, dan persepsi siswa terhadap prestasi belajar matematika siswa. Prosiding Seminar Nasional Pendidikan Matematika Etnomatnesia. 721-724.

Ratnasari, L. (2017). Pengembangan kartu permainan teka-teki silang (tts) untuk meningkatkan hasil belajar siswa pada materi sel kelas XI SMA. BioEdu, 6(2).

Renninger, K. A. (2000). Individual interest and its implications for understanding intrinsic motivation. Academic Press

Riley, R. D., Lambert, P. C., \& Abo-Zaid, G. (2010). Meta-analysis of individual participant data: rationale, conduct, and reporting. Bmj, 340, 1-7.

Safitri, D. (2012). Pengaruh kedisiplinan dan minat belajar terhadap prestasi belajar matematika siswa kelas V SD muhammadiyah 3 Surakarta. Universitas Muhammadiyah Surakarta.

Schoenfeld, A. H. (2016). Learning to think mathematically: Problem solving, metacognition, and sense making in mathematics. Journal of Education, 196(2), 1-38.

Siagian, R. E. F. (2015). Pengaruh minat dan kebiasaan belajar siswa terhadap prestasi belajar matematika. Formatif: Jurnal Ilmiah Pendidikan MIPA, 2(2), 122-131.

Sirait, E. D. (2016). Pengaruh minat belajar terhadap prestasi belajar matematika. Formatif: Jurnal Ilmiah Pendidikan MIPA, 6(1).

Sokolowski, H. M., \& Ansari, D. (2017). Who is afraid of math? What is math anxiety? And what can you do about it. Frontiers for Young Minds, 5(57), 1-7.

Stanley, T. D., Doucouliagos, H., Giles, M., Heckemeyer, J. H., Johnston, R. J., Laroche, P., Nelson, J. P., Paldam, M., Poot, J., \& Pugh, G. (2013). Meta-analysis of economics research reporting guidelines. Journal of Economic Surveys, 27(2), 390-394.

Széll, K. (2013). Factors determining student achievement. Hungarian Educational Researcch Journal, 3(3), 55-66.

Trautwein, U., Lüdtke, O., Nagy, N., Lenski, A., Niggli, A., \& Schnyder, I. (2015). Using individual interest and conscientiousness to predict academic effort: Additive, synergistic, or compensatory effects? Journal of Personality and Social Psychology, 109(1), 142-162.

Wahid, A. (2009). Korelasi Antara Minat Dengan Prestasi Belajar Matematika Siswa Kelas X MAN 1 Martapura Gambut Tahun Pelajaran 2008/2009.

Wardiana, I. P. A., Wiarta, I. W., \& Zulaikha, S. (2014). Hubungan antara adversity quotient (AQ) dan minat belajar dengan prestasi belajar matematika pada siswa kelas $\mathrm{v}$ sd di kelurahan pedungan. MIMBAR PGSD Undiksha, 2(1).

Weber, K., Martin, M. M., \& Cayanus, J. L. (2005). Student interest: A two-study reexamination of the concept. Communication Quarterly, 53(1), 71-86.

White, I. R. (2015). Network meta-analysis. The Stata Journal, 15(4), 951-985.

Winne, P. H., \& Nesbit, J. C. (2010). The psychology of academic achievement. Annual Review of Psychology, 61, 653-678. 